\title{
Revista Colombiana de

EDITORIAL

\section{COVID-19 and ACE -inhibitors and angiotensin receptor blockers-: The need to differentiate between early infection and acute lung injury}

\section{COVID-19 y IECA-inhibidores y bloqueadores de los receptores de angiotensina-: la necesidad de diferenciar entre una infección temprana y una lesión pulmonar aguda}

\author{
José Manuel González-Rayas a,*, Ana Lilia Rayas-Gómez ${ }^{\mathrm{b}}$, \\ José Juan García-González ${ }^{\mathrm{b}}$, José Manuel González-Yáñez ${ }^{\mathrm{b}}$, \\ José Ascención Hernández-Hernández ${ }^{c}$, Rosa del Carmen López-Sánchez ${ }^{d}$

\footnotetext{
a School of Medicine and Health Sciences, Monterrey Institute of Technology and Higher Education, Monterrey, México

b Hospital San José de Querétaro, Querétaro, México México

d School of Medicine and Health Sciences, Basic Science Department. Monterrey Institute of Technology and Higher Education, Monterrey, México
} \\ c School of Medicine and Health Sciences, Cancer Research. Monterrey Institute of Technology and Higher Education, Monterrey,
}

Received 5 April 2020; accepted 13 April 2020

Available online 22 April 2020

SARS-CoV-2, along with SARS-CoV and MERS-CoV, forms part of the three highly pathogenic coronaviruses identified since the start of the millennium. ${ }^{1,2}$ While SARS-CoV was identified on 2003 and MERS-CoV on 2012, the initial reports of SARSCoV-2 (the etiological agent of COVID-19) were first released at the end of December 2019.3,4 Now, after less than four months, the virus has distributed globally and has become the focus of extensive medical research, as the number of cases keeps rising Figure 1.

\footnotetext{
* Corresponding author.

E-mail address: contact.jmgr@gmail.com (J.M. González-Rayas).
}

A significant part of the investigative effort has been directed to the search for an effective therapy or intervention that could stop the spread of the disease or be used to effectively treat infected patients. Likewise, potential predisposing factors to develop a more severe clinical presentation are progressively being identified. Some of the more relevant are older age and the presence of certain comorbidities, such as cerebrovascular and coronary heart disease, hypertension and diabetes. ${ }^{5-8}$ It is important to highlight that the last two are chronic conditions commonly treated with ACE-inhibitors and angiotensin II type-I receptor blockers. ${ }^{9-11}$ However, the evidence suggests that these medications can upregulate the expression of angiotensin converting enzyme 2 (ACE2), the cellular receptor for both 


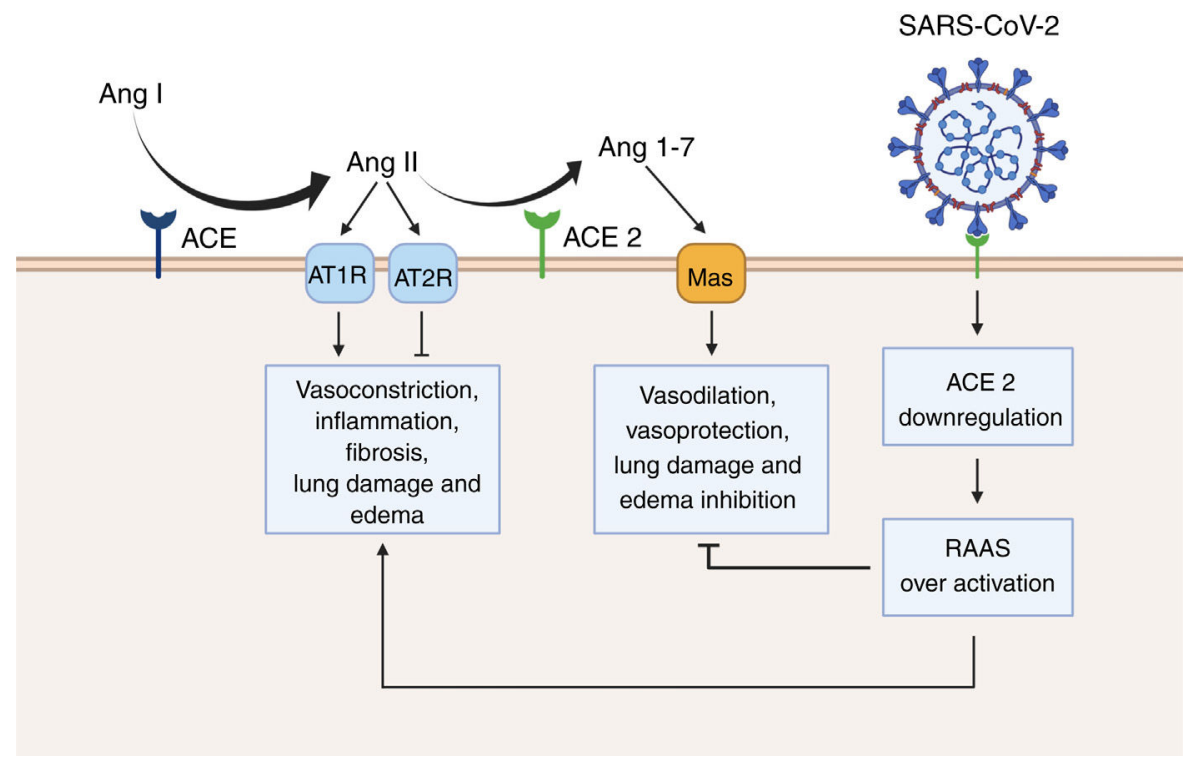

Figure 1 Renin angiotensin system (RAAS) overactivation as a result of SARS-CoV-2 infection. In physiological conditions, the angiotensin converting enzyme (ACE) metabolizes angiotensin I (Ang I) to angiotensin II (Ang II), thus leading to increased vasoconstriction, inflammation, fibrosis, lung damage and edema. Conversely, angiotensin converting enzyme 2 (ACE 2) inactivates Ang I by generating angiotensin 1-7 (Ang 1-7), which then interacts with the G-protein-coupled receptor Mas. This interaction is known to be vasoprotective, since it antagonizes the actions of Ang I. However, SARS-CoV-2 downregulates the expression of ACE2, thus leading to RAAS overactivation and to increased lung damage and edema. Created with BioRender.com.

SARS-CoV and SARS-CoV-2. ${ }^{11-16}$ Thus, a group of researchers hypothesized that ACE2-increasing drugs could raise the risk of infection and prompt a more severe clinical course or a fatal outcome in diabetic and hypertensive patients. ${ }^{11}$

As a result, the safety of ACE-inhibitors and angiotensin receptor blockers in COVID-19 patients was put into question and an intense debate arose. Nonetheless, although the idea of the intensification of ACE2 receptor expression, leading to an increased risk of COVID-19 infection is reasonable, hypertension and diabetes are also frequent comorbidities of MERS-CoV. ${ }^{17}$ The latter is relevant since MERS-CoV uses a distinct host-cell receptor, namely the dipeptidyl peptidase 4 (DPP4), also known as CD26. Hence, it would seem that the relation between chronic conditions and SARS-CoV-2 could be explained by the general pathology of coronavirus infection itself rather than by the type of receptor the virus uses.

Furthermore, we suggest that SARS-CoV-2 infection should not just be considered as a single but as a dual phase phenomenon. Therefore, in the first phase of SARS-CoV-2 infection, expressing a higher number of ACE2 receptors could indeed promote viral entry. ${ }^{11}$ However, in a second or a later phase of the infection, ACE2 receptors may be protective of SARS-CoV-2 mediated acute lung injury. ${ }^{18,19}$ In fact, experimental evidence shows that SARS-CoV infection is paired with a decrease in the expression of ACE2. ${ }^{18-20}$ As a consequence, the physiological antagonism of ACE2 over the classical renin-angiotensin-aldosterone system (RAAS) is blunted. In normal circumstances, the vasoconstrictor peptide angiotensin II is metabolized by ACE2 to produce angiotensin 1-7 (Ang 1-7). ${ }^{18}$ Ang 1-7 is then able to interact with Mas, a G-protein-coupled receptor with known vasoprotective effects. ${ }^{18,19,21,22}$ Moreover, Ang 1-7 has been shown to reduce inflammation, tissue damage and lung edema in the set of acute respiratory distress syndrome. ${ }^{23}$ This suggests that along with the viral load and the host immune response to SARS-CoV-2, an over-active RAAS could contribute to the exacerbated lung injury generated by COVID-19. Thus, recombinant ACE2 may be an effective therapeutic approach to treat COVID-19 cases, as some studies already suggest. ${ }^{24}$ Additionally, cyclic Ang 1-7, which shows increased resistance to human peptidases, such as angiotensin-converting enzyme (ACE) and dipeptidyl peptidase 3 (DPP3), could counteract the downregulation of ACE2 caused by SARS-CoV2 infection. ${ }^{25,26}$

Finally, it is important to mention that the protease (Ang 1-7 generation) and the SARS-CoV receptor functions of ACE2 are independent. ${ }^{18}$ In consequence, catalytically inactive ACE2 receptors can still interact with viral particles. Moreover, ACE2 is still active while the SARS spike proteins is bound. ${ }^{18,27}$ This is important, since it opens the possibility for the development of selective drugs that specifically target the ACE2 domain used by the SARS-CoV-2 to enter the host-cell without affecting the production of Ang 1-7. Nonetheless, intensive experimental and clinical research should validate the feasibility of this approach.

\section{Conflicts of interest}

The authors report no conflicts of interest.

\section{Funding}

None. 


\section{Acknowledgements}

None.

\section{References}

1. Chen J. Pathogenicity and transmissibility of 2019-nCoV-A quick overview and comparison with other emerging viruses. Microbes and Infection. 2020;22:69-71.

2. Perlman S. Another Decade Another Coronavirus. N Engl J Med. 2020 20;382:760-2.

3. Cortellis. Disease Briefing: Coronaviruses [Internet]. Clarivate Analytics; 2020 [cited 2020 Mar 17]. Available from: https://clarivate.com/wpcontent/uploads/dlm_uploads/2020/01/CORONAVIRUSREPORT-03.04.2020.pdf.

4. Gralinski EL, Menachery DV. Return of the Coronavirus: 2019nCoV. Viruses. 2020;12.

5. González-Rayas JM. COVID-19: possible accelerated progression to a fatal outcome for elder patients [Internet]. Open Science Framework. 2020 Mar [cited 2020 Apr 4]. Available from: https://osf.io/mgv5u.

6. Yang X, Yu Y, Xu J, Shu H, Xia J, Liu H, et al. Clinical course and outcomes of critically ill patients with SARS-CoV2 pneumonia in Wuhan China: a single-centered, retrospective, observational study. The Lancet Respiratory Medicine. 2020 Feb. S2213260020300795.

7. Guan W, Ni Z, Hu Y, Liang W, Ou C, He J, et al. Clinical Characteristics of Coronavirus Disease 2019 in China. N Engl J Med. 2020 Feb 28. NEJMoa2002032.

8. Zhang J, Dong X, Cao Y, Yuan Y, Yang Y, Yan Y, et al. Clinical characteristics of 140 patients infected with SARS-CoV-2 in Wuhan. China. Allergy. 2020 Feb 27:14238, all.

9. Tocci G, Paneni F, Palano F, Sciarretta S, Ferrucci A, Kurtz T, et al., Angiotensin-Converting Enzyme Inhibitors, Angiotensin II. Receptor Blockers and Diabetes: A Meta-Analysis of PlaceboControlled Clinical Trials. Am J Hypertension. 2011;24:582-90.

10. Ramos-Nino ME, Blumen SR. Benefits of ACE Inhibitors in Diabetes. Clinical Medicine Therapeutics. 2009;1. CMT.S2027.

11. Fang $L$, Karakiulakis $G$, Roth $M$. Are patients with hypertension and diabetes mellitus at increased risk for COVID-19 infection? The Lancet Respiratory Medicine. 2020. S2213260020301168.

12. Ingelfinger JR. ACE2: A New Target for Prevention of Diabetic Nephropathy?: Figure 1. JASN. 2006;17:2957-9.

13. Tikellis C, Thomas MC. Angiotensin-Converting Enzyme 2 (ACE2) Is a Key Modulator of the Renin Angiotensin System in Health and Disease. International Journal of Peptides. 2012;. 2012:1-8.

14. Ferrario CM, Jessup J, Chappell MC, Averill DB, Brosnihan KB, Tallant EA, et al. Effect of Angiotensin-Converting Enzyme Inhibition and Angiotensin II Receptor Blockers on Cardiac Angiotensin-Converting Enzyme 2. Circulation. 2005; 111:2605-10.

15. Huang $M$, Li X, Meng $Y$, Xiao B, Ma Q, Ying S, et al. Upregulation of angiotensin-converting enzyme (ACE) 2 in hepatic fibrosis by ACE inhibitors. Clinical and Experimental Pharmacology and Physiology. 2010;37:e1-6.

16. Chamsi-Pasha MAR, Shao Z, Tang WHW. Angiotensin-Converting Enzyme 2 as a Therapeutic Target for Heart Failure. Curr Heart Fail Rep. 2014;11:58-63

17. Alqahtani FY, Aleanizy FS, Ali El Hadi Mohamed R, Alanazi MS, Mohamed N, Alrasheed MM, et al. Prevalence of comorbidities in cases of Middle East respiratory syndrome coronavirus: a retrospective study. Epidemiol Infect. 2019;147:e35.

18. Kuba K, Imai Y, Ohto-Nakanishi T, Penninger JM. Trilogy of ACE2: A peptidase in the renin-angiotensin system, a SARS receptor, and a partner for amino acid transporters. Pharmacology \& Therapeutics. 2010;128:119-28.

19. Hendrickson C, Matthay M. Viral Pathogens and Acute Lung Injury: Investigations Inspired by the SARS Epidemic and the 2009 H1N1 Influenza Pandemic. Semin Respir Crit Care Med. 2013 Aug 11;34:475-86.

20. Kuba K, Imai Y, Rao S, Gao H, Guo F, Guan B, et al. A crucial role of angiotensin converting enzyme 2 (ACE2) in SARS coronavirus-induced lung injury. Nat Med. 2005;11:875-9.

21. Nájera N, Martínez-Vega RP, Portilla-Martínez A, Ortiz-Vilchis P, Ceballos G. G-proteins coupled receptors. Cardiovascular and Metabolic Science. 2019;30(2.).

22. Simões e Silva A, Silveira K, Ferreira A, Teixeira M. ACE2, angiotensin-(1-7) and Mas receptor axis in inflammation and fibrosis: Angiotensin-(1-7) in inflammation and fibrosis. $\mathrm{Br} \mathrm{J}$ Pharmacol. 2013;169:477-92.

23. Wösten-van Asperen RM, Lutter R, Specht PA, Moll GN, van Woensel JB, van der Loos CM, et al. Acute respiratory distress syndrome leads to reduced ratio of ACE/ACE2 activities and is prevented by angiotensin-(1-7) or an angiotensin II receptor antagonist. J Pathol. 2011;225:618-27.

24. Monteil V, Kwon H, Prado P, Hagelkrüys A, Wimmer RA, Stahl M, et al. Inhibition of SARS-CoV-2 infections in engineered human tissues using clinical-grade soluble human ACE2. 29.

25. Cassis P, Locatelli M, Corna D, Villa S, Rottoli D, Cerullo $D$, et al. Addition of cyclic angiotensin-(1-7) to angiotensinconverting enzyme inhibitor therapy has a positive add-on effect in experimental diabetic nephropathy. Kidney International. 2019;96:906-17.

26. Wester A, Devocelle M, Tallant EA, Chappell MC, Gallagher PE, Paradisi F. Stabilization of Angiotensin-(1-7) by key substitution with a cyclic non-natural amino acid. Amino Acids. 2017;49:1733-42.

27. Li F, Li W, Farzan M, Harrison SC. Structure of SARS Coronavirus Spike Receptor-Binding Domain Complexed with Receptor. Science. 2005;309:1864. 